\title{
Membrane Estrogen Receptors Stimulate Intracellular Calcium Release and Progesterone Synthesis in Hypothalamic Astrocytes
}

\author{
John Kuo, ${ }^{1,2}$ Naheed Hamid, ${ }^{1}$ Galyna Bondar, ${ }^{1}$ Eric R. Prossnitz, ${ }^{3}$ and Paul Micevych ${ }^{1}$ \\ ${ }^{1}$ Department of Neurobiology, Laboratory of Neuroendocrinology of the Brain Research Institute, ${ }^{2}$ Department of Obstetrics and Gynecology, David Geffen \\ School of Medicine at UCLA, Los Angeles, California 90095, and ${ }^{3}$ Department of Cell Biology and Physiology, University of New Mexico Health Science \\ Center, Albuquerque, New Mexico 87131
}

In hypothalamic astrocytes obtained from adult female rats, estradiol rapidly increased free cytoplasmic calcium concentrations $\left(\left[\mathrm{Ca}^{2+}\right]_{\mathrm{i}}\right)$ that facilitate progesterone synthesis. The present study demonstrated that estradiol (1 nu) significantly and maximally stimulated progesterone synthesis within $5 \mathrm{~min}$, supporting a rapid, nongenomic mechanism. The group I metabotropic glutamate receptor (mGluRla) antagonist LY $367385[(S)-(+)$-a-amino-4-carboxy-2-methylbenzeneacetic acid] attenuated both the estradiolinduced $\left[\mathrm{Ca}^{2+}\right]_{\mathrm{i}}$ release and progesterone synthesis. To investigate membrane-associated estrogen receptors (mERs), agonists for ER $\alpha$, $\mathrm{ER} \beta$, STX-activated protein, and GPR30 were compared. The selective ER $\alpha$ agonist propylpyrazole triole (PPT) and STX most closely mimicked the estradiol-induced $\left[\mathrm{Ca}^{2+}\right]_{\mathrm{i}}$ responses, where PPT was more potent but less efficacious than STX. Only high doses (100 nM) of selective ER $\beta$ agonist diarylpropionitrile (DPN) and GPR30 agonist G-1 induced estradiol-like $\left[\mathrm{Ca}^{2+}\right]_{\mathrm{i}}$ responses. With the exception of DPN (even at $100 \mathrm{~nm}$ ), all agonists stimulated progesterone synthesis. The PPT- and STX-induced $\left[\mathrm{Ca}^{2+}\right]_{\mathrm{i}}$ release and progesterone synthesis were blocked by LY 367385. While the G-1-stimulated $\left[\mathrm{Ca}^{2+}\right]_{i}$ release was blocked by LY 367385, progesterone synthesis was not. Since GPR30 was detected intracellularly but not in the membrane, we interpreted these results to suggest that G-1 could activate mGluRla on the membrane and GPR30 on the smooth endoplasmic reticulum to release intracellular calcium. Although STX and G-1 maximally stimulated $\left[\mathrm{Ca}^{2+}\right]_{\mathrm{i}}$ release in astrocytes from estrogen receptor- $\alpha$ knock-out (ERKO) mice, estradiol in vivo did not stimulate progesterone synthesis in the ERKO mice. Together, these results indicate that $\mathrm{mER} \alpha$ is mainly responsible for the rapid, membraneinitiated estradiol-signaling that leads to progesterone synthesis in hypothalamic astrocytes.

\section{Introduction}

It is now well accepted that estradiol acts on hypothalamic astrocytes (Micevych et al., 2008). Estradiol can activate classical nuclearinitiated and/or membrane-initiated mechanisms. Nuclearinitiated estradiol action is well established and results through activation of intracellular $\mathrm{ER} \alpha$ and $\mathrm{ER} \beta$. Although long-studied, it is only more recently that membrane-initiated estradiol action has been accepted (Szego and Davis, 1967; Kelly et al., 1976; Lagrange et al., 1995; Razandi et al., 1999; Filardo et al., 2000; Ivanova et al., 2001; Wade et al., 2001; Qiu et al., 2003; Chaban et al., 2004; Acconcia et al., 2005; Pawlak et al., 2005; Revankar et al., 2005; Thomas et al., 2005; Mhyre and Dorsa, 2006; Pedram et al., 2006, 2007; Bondar et al., 2009; Hirahara et al., 2009; Kuo et al., 2009b).

As in neurons, estradiol acts to alter cell signaling in astro-

Received March 5, 2010; revised July 22, 2010; accepted July 28, 2010.

This work was supported by National Institutes of Health (NIH) Grants HD42635 and HD001281, and the Reproductive Scientist Development Program through NIH Grant HD00849-23 and Bayer HealthCare Pharmaceuticals. We appreciate and thank Dr. Thomas Scanlan at the Oregon Health and Science University, Portland, Oregon, for kindly providing the STX used in our experiments.

Correspondence should be addressed to Dr. Paul Micevych, Department of Neurobiology, David Geffen School of Medicine at UCLA, 10833 LeConte Avenue, 73-078 CHS, Los Angeles, CA 90095-1763. E-mail: pmicevych@mednet. ucla.edu.

DOI:10.1523/JNEUROSCI.1158-10.2010

Copyright $\odot 2010$ the authors $\quad 0270-6474 / 10 / 3012950-08 \$ 15.00 / 0$ cytes, which express ER $\alpha$ and ER $\beta$ both intracellularly and on the plasma membrane (Garcia-Segura et al., 1999; Chaban et al., 2004; Pawlak et al., 2005; Quesada et al., 2007). In astrocytes, estradiol induces a rapid $\left[\mathrm{Ca}^{2+}\right]_{\mathrm{i}}$ increase via the phospholipase $\mathrm{C} /$ inositol trisphosphate $\left(\mathrm{PLC} / \mathrm{IP}_{3}\right)$ pathway releasing intracellular stores of calcium (Beyer and Raab, 1998; Chaban et al., 2004). This $\left[\mathrm{Ca}^{2+}\right]_{\mathrm{i}}$ release facilitates the synthesis of progesterone in astrocytes (Micevych et al., 2007), which is essential for positive estrogen feedback, the LH surge, and ovulation (Micevych and Sinchak, 2008b; Micevych et al., 2008). We have demonstrated that membrane-initiated estradiol signaling involves ER $\alpha$ transactivation of mGluRla (Kuo et al., 2009b). Recently, surface biotinylation has confirmed a membrane-associated estrogen receptor- $\alpha(\mathrm{mER} \alpha)$ with an extracellular portion (Bondar et al., 2009).

In addition to $\operatorname{mER} \alpha$ and $\operatorname{mER} \beta$, several other candidate mERs have been reported in neurons (Qiu et al., 2003; Brailoiu et al., 2007; Sakamoto et al., 2007). One such candidate is GPR30, a G-protein-coupled receptor (GPCR) (Filardo et al., 2000; Revankar et al., 2005; Thomas et al., 2005). Another candidate is a G $\alpha$ q-coupled membrane-associated receptor that is activated by STX, a diphenylacrylamide selective estrogen receptor modulator (SERM) (Qiu et al., 2003). The present experiments were done to 
compare these putative mERs on the rapid activation of intracellular signaling pathways in hypothalamic astrocytes. Estradiol was used as the quintessential mER agonist and compared with selective agonists for $\mathrm{ER} \alpha, \mathrm{ER} \beta, \mathrm{GPR} 30$, and STX-activated protein, also known as G $\alpha$ q-mER. Except for DPN, the other putative $\mathrm{mER}$ candidates induced $\mathrm{a}\left[\mathrm{Ca}^{2+}\right]_{\mathrm{i}}$ release and progesterone synthesis, but G-1 required a very high dose (100 nM). Similar to estradiol, PPT and STX required transactivation of mGluR1a indicating a membrane-mediated mechanism, while G-1 facilitated progesterone synthesis independent of mGluRla. Coimmunoprecipitation also failed to demonstrate a direct interaction between mGluR1a and ER $\beta$ or GPR30. The estradiol-induced $\left[\mathrm{Ca}^{2+}\right]_{\mathrm{i}}$ response was significantly attenuated in ERKO mouse astrocytes, suggesting estradiol signaling through $\mathrm{mER} \alpha$. G-1 and STX signaled independently from $\operatorname{mER} \alpha$, and DPN did not replicate estradiol-like responses. Interestingly, estradiol-like signaling at the membrane involved the mGluRla as monitored by $\left[\mathrm{Ca}^{2+}\right]_{\mathrm{i}}$ release and progesterone synthesis in hypothalamic astrocytes.

\section{Materials and Methods}

Primary cell cultures. Primary hypothalamic astrocyte cultures were obtained from 50-d-old, postpubertal, Long-Evans female rats (Charles River) and from 60-d-old female mice (C57BL/6 wild-type and ER $\alpha$ knock-out from The Jackson Laboratory). All experimental procedures were approved by the Chancellor's Animal Research Committee at the University of California at Los Angeles. The hypothalamus was dissected with the following boundaries: rostral extent of the optic chiasm, rostral extent of the mammillary bodies, lateral edges of the tuber cinereum, and the top of the third ventricle. The hypothalamus was enzymatically digested with trypsin and mechanically dissociated with a fire-polished glass Pasteur pipette. Cultures were grown for 7-10 d in DMEM/F12 (Mediatech) with 10\% FBS (Hyclone) and $1 \%$ penicillin $(10,000 \mathrm{IU} / \mathrm{ml})$ streptomycin $(10,000 \mu \mathrm{g} / \mathrm{ml})$ solution (PS; Mediatech) at $37^{\circ} \mathrm{C}$. Astrocyte cultures were grown to confluency and then purified from other glial cells using a technique (Sinchak et al., 2003; Micevych et al., 2007; Kuo et al., 2009b) modified from McCarthy and de Vellis (McCarthy and de Vellis, 1980). Briefly, flasks were placed on an orbital shaker at $200 \mathrm{rpm}$ for at least $24 \mathrm{~h}$ at $37^{\circ} \mathrm{C}$ to eliminate oligodendrocytes. Culture medium was replaced after every shaking sequence.

Before experimentation, DMEM/F12 medium with 10\% FBS and 1\% PS was removed from the flasks and primary astrocyte cultures were washed with Hanks' balanced salt solution (HBSS; Mediatech), dissociated with a $2.5 \%$ trypsin solution, and then resuspended in DMEM/F12 medium with $10 \%$ FBS. Astrocytes were centrifuged for 3 min at $80 \times g$, the supernatant was removed, and the pellet containing astrocytes was resuspended. Astrocytes were counted, plated, and incubated in DMEM/ F12 medium with $10 \%$ FBS and $1 \%$ PS at $37^{\circ} \mathrm{C}$ for $24-48 \mathrm{~h}$ before $\mathrm{Ca}^{2+}$ imaging and progesterone radioimmunoassay (RIA). For coimmunoprecipitation, astrocytes were counted, plated, and grown for 2 weeks before astrocyte cultures were collected for experimentation. Cultures were routinely checked for purity using immunocytochemistry for glial fibrillary acidic protein (GFAP) (Millipore Bioscience Research Reagents) with a Hoechst 3342 (Sigma-Aldrich) nuclear stain. Cultures were determined to be $>95 \%$ pure astrocytes as previously reported (Sinchak et al., 2003; Micevych et al., 2007; Kuo et al., 2009b).

Intracellular $\mathrm{Ca}^{2+}$ measurements. Five thousand astrocytes were plated onto poly-D-lysine $(0.1 \mathrm{mg} / \mathrm{ml}$; Sigma-Aldrich)-coated $15 \mathrm{~mm}$ glass coverslips in 12-well culture plates and grown in DMEM/F12 medium with $10 \% \mathrm{FBS}$ and $1 \%$ PS at $37^{\circ} \mathrm{C}$ for $24-48 \mathrm{~h}$. The astrocytes were then steroid starved for $18 \mathrm{~h}$ by incubating in DMEM/F12 medium with 5\% charcoal-stripped $\mathrm{FBS}$ at $37^{\circ} \mathrm{C}$. Immediately before imaging, astrocytes were incubated at $37^{\circ} \mathrm{C}$ for $45 \mathrm{~min}$ with HBSS and a calcium indicator, Fluo-4 AM (4.5 $\mu \mathrm{M}$; Invitrogen), DMSO, and methanol. The cells were then washed three times with HBSS. Glass coverslips were mounted into a $50 \mathrm{~mm}$ chamber insert (Warner Instruments) fixed into a $60 \times 15 \mathrm{~mm}$ cell culture dish (Corning) and placed into a QE-2 quick exchange plat- form (Warner Instruments) for imaging on the Axioplan2-LSM 510 Meta confocal microscope (Zeiss). Astrocytes were gravity perfused with HBSS and removed by vacuum suction. Fluo-4 AM imaging was performed using an IR-Achroplan $40 \times / 0.80$ water-immersion objective (Zeiss) with $488 \mathrm{~nm}$ laser excitation and emission monitored through a low-pass filter with a cutoff at $505 \mathrm{~nm}$. The increase in $\mathrm{Ca}^{2+}$ fluorescence (relative fluorescence units or RFU) was calculated as the difference between baseline fluorescence and peak response to drug stimulation.

Drugs were delivered by gravity perfusion and used in the following concentrations: 1 pM to $100 \mathrm{~nm}$ PPT (Sigma-Aldrich); $1 \mathrm{~nm}$ to $10 \mu \mathrm{M}$ DPN (Tocris Bioscience); 100 pm to 100 nM STX (courtesy of Dr. Thomas Scanlan, Oregon Health and Science University, Portland, OR); $1 \mathrm{~nm}$ to $10 \mu \mathrm{m}$ G-1 (Chemical Diversity Labs); 20 nм LY 367385 [( $S)-(+)-a-$ amino-4-carboxy-2-methylbenzeneacetic acid] (Tocris Bioscience); and 100 nм DHPG (Tocris Bioscience). Stock solutions and final working concentrations were prepared in HBSS. Controls were stimulated with HBSS only.

Progesterone radioimmunoassay. One-half million astrocytes were plated into 6-well culture plates and grown for $24 \mathrm{~h}$. Astrocytes were then steroid starved for $18 \mathrm{~h}$ before experimentation. In assays involving the mGluR1a antagonist LY 367385, astrocyte cultures were first steroid starved in DMEM/F12 medium with 5\% charcoal-stripped FBS for $17.5 \mathrm{~h}$, washed with HBSS, and then incubated for $30 \mathrm{~min}$ with control or LY 367385 dissolved in HBSS to preblock the mGluR1a before stimulation with the experimental drugs. Following the $18 \mathrm{~h}$ steroid starvation, culture medium was removed, $1 \mathrm{ml}$ of drug was added to each well and incubated for 5 or $60 \mathrm{~min}$, the supernatant was collected, and the samples were frozen at $-20^{\circ} \mathrm{C}$ for up to 1 week before the RIA.

For progesterone RIA, samples were thawed, mixed with diethyl ether (Fisher Scientific), and vortexed for $2 \mathrm{~min}$. Samples were then placed into a methanol and dry ice bath to freeze the aqueous layer. The upper ether layer was decanted into a separate tube and the ether was allowed to evaporate overnight. The extract was reconstituted in isooctane (Mallinkrodt Baker) and a Celite column with ethylene glycol as the stationary phase was used to isolate the progesterone. Progesterone was then eluted off the column using $4 \mathrm{ml}$ of isooctane. Standards and samples $(100 \mu \mathrm{l})$ were incubated with rabbit polyclonal antibody against progesterone (Sigma-Aldrich) for $30 \mathrm{~min}$ at $37^{\circ} \mathrm{C}$. Tritium-radiolabeled progesterone $(2000 \mathrm{cpm} / \mathrm{ml})$ was then added and incubated for an additional $60 \mathrm{~min}$ at $37^{\circ} \mathrm{C}$. Standards and samples were cooled at $4^{\circ} \mathrm{C}$ and a $0.05 \%$ charcoal dextran solution (Sigma-Aldrich) added to remove all unbound progesterone. The mixture was centrifuged (3000 rpm) for 15 $\min$ at $4^{\circ} \mathrm{C}$. The supernatant was collected for chromatographic detection of progesterone. All samples were run in duplicate and sample progesterone concentrations determined by extrapolation from a curve determined from the progesterone standards. The intra-assay variance for the progesterone RIA was $3.16 \%$.

Drugs were used in the following concentrations: 100 pM to $1 \mu \mathrm{M}$ cyclodextrin-encapsulated $17 \beta$-estradiol (Sigma-Aldrich); 50 nм LY 367385 (Tocris Bioscience); $100 \mathrm{~nm}$ DHPG (Tocris Bioscience); $1 \mathrm{~nm}$ PPT; 100 nм DPN; 1 nм STX; and 100 nм G-1. Stock solutions and final working concentrations were prepared in HBSS. Controls were stimulated with HBSS only.

Coimmunoprecipitation. Two-week-old primary astrocyte cultures $(\sim 5$ million cells per sample) were washed three times with PBS (PBS; Mediatech) and collected by mechanical scraping (Corning). The cell suspensions were passed through a 25 -gauge needle ( $\sim 60$ times) in 50 mм Tris- $\mathrm{HCl}$ buffer, $\mathrm{pH} 7.5$, with $1 \% N$-dodecyl- $\beta$-D-maltopyranoside (DDM) (Anatrace, Affymetrix) and protease inhibitors (1 mM phenylmethylsulfonyl fluoride, $1 \mathrm{~mm}$ EDTA, $1 \mu \mathrm{g} / \mathrm{ml}$ pepstatin, $1 \mu \mathrm{g} / \mathrm{ml} \mathrm{leu}-$ peptin, and $1 \mu \mathrm{g} / \mathrm{ml}$ aprotinin-all from Roche). Samples were placed on ice for $30 \mathrm{~min}$ and centrifuged $\left(600 \times g\right.$ for $\left.10 \mathrm{~min}, 4^{\circ} \mathrm{C}\right)$. The supernatant was used for coimmunoprecipitation and the pellet was discarded. Membrane fractions were obtained with a Mem-PER Membrane Protein Extraction Kit (Pierce Biotechnology) with 1\% DDM to optimize protein extraction.

Concentrations of membrane and whole-cell lysate proteins were determined by the Bradford method (Bio-Rad) (Bradford, 1976). Similar concentrations of membrane and whole-cell lysate proteins $(1.5 \mathrm{mg} / \mathrm{ml}$; 
sample volume $\sim 250 \mu \mathrm{l}$ ) were used. Endogenous antibodies were removed by incubating $\left(30 \mathrm{~min}, 4^{\circ} \mathrm{C}\right)$ with Protein-G Sepharose 4 Fast Flow (100 $\mu$; GE Healthcare). The samples were centrifuged $(850 \times g$ for $5 \mathrm{~min}$ ) and the supernatants retained. Rabbit polyclonal antibody against mGluR1a (1:100; Millipore) was added to the supernatants and placed on a rotating stirrer at $4^{\circ} \mathrm{C}$ for $1 \mathrm{~h}$. The antibody-protein complex was adsorbed with $100 \mu \mathrm{l}$ of Protein-G Sepharose 4 Fast Flow according to the manufacturer's protocol. The solutions were rotated overnight at $4^{\circ} \mathrm{C}$, and then washed 10 times with $20 \mathrm{~mm}$ sodium phosphate, $\mathrm{pH}$ 7.0, containing $0.2 \%$ DDM. The adsorbed proteins were eluted from the beads with $0.1 \mathrm{M}$ of glycine, $\mathrm{pH} 3.0$, containing $0.2 \%$ DDM, then $1 \mathrm{M}$ of Tris$\mathrm{HCl}$ buffer, $\mathrm{pH}$ 8.0, was used to adjust the solution to $\mathrm{pH}$ 7.5.

Samples were mixed with an equal volume of SDS sample buffer $(2 \%$ SDS, $5 \% \beta$-mercaptoethanol, $10 \%$ glycerol, $0.004 \%$ bromophenol blue, and $0.1 \mathrm{M}$ Tris $\mathrm{HCl}$; $\mathrm{pH} 6.8$ ) and run by SDS-PAGE using a $10 \%$ polyacrylamide gradient (Ready Gels; Bio-Rad). Astrocyte whole-cell lysate without coimmunoprecipitation served as a positive control. Proteins were electrically transferred onto polyvinylidene difluoride membranes (GE Healthcare) and probed with rabbit polyclonal antibody against ER $\beta$ (1:1000; Millipore) or rabbit polyclonal antibody against GPR30 (1:1000; MBL International) for $1 \mathrm{~h}$, followed by an $1.5 \mathrm{~h}$ incubation with a secondary donkey anti-rabbit $\operatorname{IgG}(\mathrm{H}+\mathrm{L})$ antibody (1:5000; Jackson ImmunoResearch). Bands were visualized using an enhanced chemiluminescence (ECL) kit and ECL Hyperfilm (GE Healthcare). Exposures varied from $0.5-2 \mathrm{~min}$. The experiments were also repeated in the reverse direction: antibodies against $\mathrm{ER} \beta$ or GPR 30 were used in the pull-down phase and complex detected with antibodies against mGluRla.

Statistics. Data are presented as means \pm SEM in RFU or pg/ml. Statistical comparisons were made using the paired Student's $t$ test when comparing paired means across 2 groups, unpaired Student's $t$ test when comparing means between 2 independent groups, and one-way ANOVA with Student-Newman-Keuls post hoc test when comparing means across 3 or more independent groups. The half-maximal effective concentration $\left(\mathrm{EC}_{50}\right)$ assessments with $95 \%$ confidence intervals (CI) were calculated by fitting four parameter logit (sigmoid) drug vs $\left[\mathrm{Ca}^{2+}\right]_{\mathrm{i}}$ release or progesterone synthesis dose-response curves using the log scale for the drug concentration. Statistical calculations were performed using Stata 11 (StataCorp LP) and GraphPad Prism 5. Differences at the $p<$ 0.05 level were considered significant.

\section{Results}

\section{Effect of estradiol on progesterone synthesis in astrocytes}

In a previous paper (Kuo et al., 2009b), we demonstrated that 100 pM estradiol significantly increased $\left[\mathrm{Ca}^{2+}\right]_{i}$ release in primary cultures of adult, female hypothalamic astrocytes. Using the same culture conditions, we now demonstrate that estradiol in a dose range of $1 \mathrm{nM}-1 \mu \mathrm{M}$ all stimulated significant and maximal progesterone synthesis ( $p<0.05$ vs control) that were similar to each other ( $p>0.05$; Fig. 1). Maximal progesterone level (64.6 \pm 6.5 $\mathrm{pg} / \mathrm{ml}, n=4)$ occurred at $1 \mu \mathrm{M}$ estradiol. Because all concentrations of estradiol $\geq 1 \mathrm{~nm}$ maximally stimulated progesterone synthesis, we subsequently tested a dose range of $250 \mathrm{pM}-1 \mathrm{~nm}$ estradiol. However, all subnanomolar doses of estradiol failed to stimulate significant progesterone synthesis $(p>0.05$; Fig. 1$)$. The $\mathrm{EC}_{50}$ of estradiol to stimulate progesterone synthesis was $821 \mathrm{pm}(95 \%$ CI: 740-911 pM). Interestingly, a 5 min estradiol ( $1 \mathrm{nM}$ ) incubation was sufficient to maximally increase the progesterone level $(56.5 \pm 9.1 \mathrm{pg} / \mathrm{ml}, n=4)$ compared with control $(0.8 \pm 0.8 \mathrm{pg} / \mathrm{ml}, n=4, p<0.05)$. Such results are congruent with the idea that progesterone synthesis in astrocytes is mediated by rapid, nongenomic estradiol signaling.

\section{Characterization of mERs involved in $\left[\mathrm{Ca}^{2+}\right]_{\mathrm{i}}$ release}

To investigate whether other estradiol binding proteins in addition to $\operatorname{ER} \alpha$ activate intracellular stores of calcium, agonists for $\mathrm{ER} \alpha, \mathrm{ER} \beta, \mathrm{GPR} 30$, and the STX-binding protein were used. Dose-response curves were generated for each agonist and com-

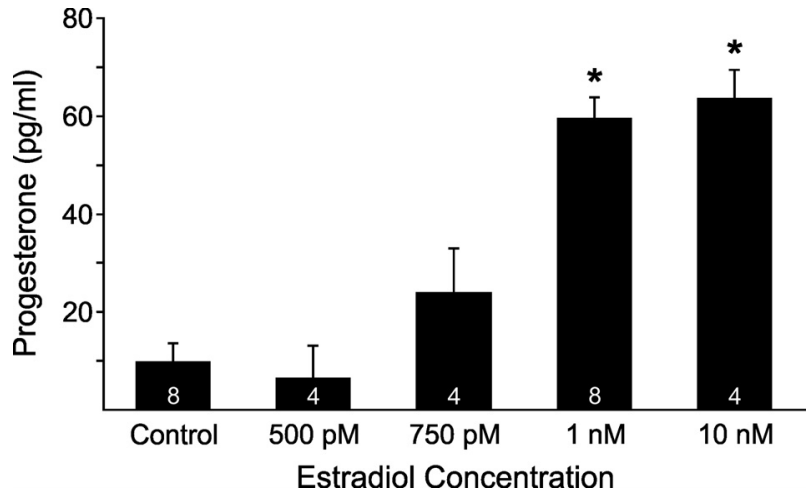

Figure 1. Dose-response relationship between estradiol stimulation and progesterone synthesis in adult hypothalamic astrocytes. Estradiol at $1 \mathrm{~nm}, 10 \mathrm{~nm}, 100 \mathrm{~nm}(62.6 \pm 7.0 \mathrm{pg} / \mathrm{ml}, n=$ 4), and $1 \mu \mathrm{m}(64.6 \pm 6.5 \mathrm{pg} / \mathrm{ml}, n=4)$ all stimulated significant and maximal progesterone synthesis ( $p<0.05$ vs control) that were similar to each other $(p>0.05)$. However, estradiol at $100 \mathrm{pm}(10.4 \pm 6.0 \mathrm{pg} / \mathrm{ml}, n=4), 250 \mathrm{pm}(10.1 \pm 10.1 \mathrm{pg} / \mathrm{ml}, n=4), 500 \mathrm{pm}$, and $750 \mathrm{pm}$ failed to stimulate progesterone synthesis ( $p>0.05$ vs control). The number of samples for each estradiol concentration is indicated in the bar graph. Significantly different compared with control ( ${ }^{*} p<0.05$, one-way ANOVA with Student-Newman-Keuls post hoc test).

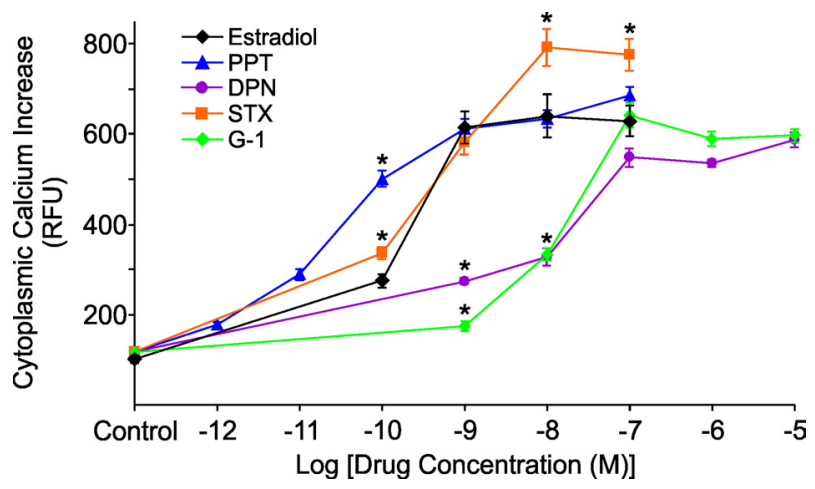

Figure 2. Comparison of dose-response relationships measured in $\left[\mathrm{Ca}^{2+}\right]_{i}$ between estradiol and several ER agonists in adult hypothalamic astrocytes. At $100 \mathrm{pm}$, the $\left[\mathrm{Ca}^{2+}\right]_{\mathrm{i}}$ response for PPT and STX were both greater than estradiol $(p<0.05)$. At $1 \mathrm{~nm}, \mathrm{PPT}$ and STX exposure resulted in an estradiol-like $\left[\mathrm{Ca}^{2+}\right]_{\mathrm{i}}$ release $(p>0.05)$, whereas DPN and $\mathrm{G}-1$ responses were significantly lower than estradiol $(p<0.05)$. At $10 \mathrm{~nm}$, PPT again induced $\left[\mathrm{Ca}^{2+}\right]_{\mathrm{i}}$ levels similar to estradiol $(p>0.05)$, STX had a greater $\left[\mathrm{Ca}^{2+}\right]_{\mathrm{i}}$ response compared with estradiol $(p<0.05)$, and DPN and $\mathrm{G}-1$ continued to have a weaker $\left[\mathrm{Ca}^{2+}\right]_{\mathrm{i}}$ response $(p<0.05)$. At 100 nM, PPT, DPN, and G-1 all induced an estradiol-like $\left[\mathrm{Ca}^{2+}\right]_{\mathrm{i}}$ release $(p>0.05)$, while STX continued to induce a greater $\left[\mathrm{Ca}^{2+}\right]_{\mathrm{i}}$ response $(p<0.05)$. There was no difference between unstimulated controls $(p>0.05)$. For all drug concentrations, a range of $14-33$ astrocytes were imaged. Significantly different compared with estradiol at the same concentration $\left({ }^{*} p<0.05\right.$, one-way ANOVA with Student-Newman-Keuls post hoc test).

pared with previous estradiol-induced $\left[\mathrm{Ca}^{2+}\right]_{\mathrm{i}}$ responses with an $\mathrm{EC}_{50}$ of $151 \mathrm{pm}(95 \% \mathrm{CI}: 94-244 \mathrm{pm})$ and maximal $\left[\mathrm{Ca}^{2+}\right]_{\mathrm{i}}$ level $(641 \pm 47 \mathrm{RFU}, n=18)$ at $10 \mathrm{~nm}$ estradiol (Kuo et al., 2009b). Although drug characteristics varied, all agonists at each concentration tested produced a statistically significant elevation of $\left[\mathrm{Ca}^{2+}\right]_{\mathrm{i}}(p<0.05$; Fig. 2$)$. At the 100 pM dose, PPT and STX were significantly more efficacious than estradiol $(p<0.05$ for PPT and STX). At $1 \mathrm{nM}, \mathrm{DPN}$ and G-1 induced a significantly lower $\left[\mathrm{Ca}^{2+}\right]_{\mathrm{i}}$ response compared with estradiol, PPT, and STX $(p<$ 0.05 for DPN and G-1). At $10 \mathrm{nM}$, STX stimulated a greater $\left[\mathrm{Ca}^{2+}\right]_{\mathrm{i}}$ response compared with estradiol and PPT $(p<0.05)$, while DPN and G-1 were significantly lower than estradiol and PPT ( $p<0.05$ for DPN and G-1). STX continued to produce the highest $\left[\mathrm{Ca}^{2+}\right]_{\mathrm{i}}$ response at $100 \mathrm{~nm}(p<0.05$ compared with estradiol), but at this concentration, DPN and G-1 were as effective as estradiol and PPT ( $p>0.05$ for DPN and G-1). 


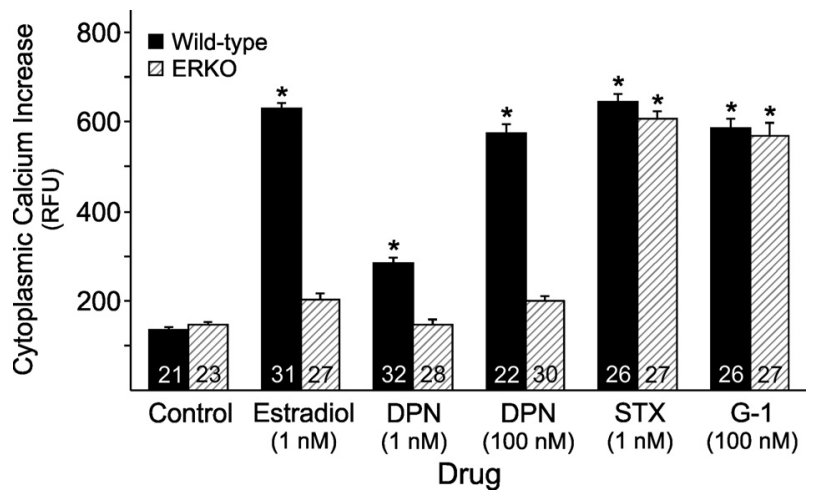

Figure 3. Importance of $m E R \alpha$ for the estradiol-induced $\left[\mathrm{Ca}^{2+}\right]_{\mathrm{i}}$ release in adult hypothalamic astrocytes. The estradiol $(1 \mathrm{~nm})$-induced $\left[\mathrm{Ca}^{2+}\right]_{\mathrm{i}}$ release was attenuated in the ERKO mouse astrocytes ( $p>0.05 \mathrm{vs}$ control). DPN ( 1 and $100 \mathrm{~nm}$ ) did not induce a $\left[\mathrm{Ca}^{2+}\right]_{\mathrm{i}}$ response ( $p>0.05$ vs control) in ERKO astrocytes. Wild-type and ERKO astrocytes were able to respond normally and equally to STX at $1 \mathrm{~nm}$ and $\mathrm{G}-1$ at $100 \mathrm{~nm}$ ( $p<0.05$ vs control). The number of astrocytes for each drug concentration is indicated in the bar graph. Significantly different compared with control $\left({ }^{*} p<0.05\right.$, one-way ANOVA with Student-Newman-Keuls post hoc test).

PPT was the most potent of the mER agonists with an $\mathrm{EC}_{50}$ of $28.3 \mathrm{pM}$ (95\% CI: $17.9-44.6 \mathrm{pM})$ and maximal $\left[\mathrm{Ca}^{2+}\right]_{\mathrm{i}}$ release $(687 \pm 19 \mathrm{RFU}, n=22)$ obtained at $100 \mathrm{~nm}$ (Fig. 2$)$. At $1 \mathrm{~nm}, 10$ $\mathrm{nM}$, and $100 \mathrm{nM}$, PPT most closely resembled an estradiol-like $\left[\mathrm{Ca}^{2+}\right]_{\mathrm{i}}$ release $(p>0.05)$. STX induced a greater maximal $\left[\mathrm{Ca}^{2+}\right]_{\mathrm{i}}$ response compared with estradiol that did not reach a plateau (792 $\pm 40 \mathrm{RFU}, n=23)$ until $10 \mathrm{nM}$, but had an estradiollike $\mathrm{EC}_{50}$ of 215 pM (95\% CI: 85-542 pM). DPN and G-1 required a high concentration (100 $\mathrm{nm}$ ) before reaching estradiol-like levels of $\left[\mathrm{Ca}^{2+}\right]_{\mathrm{i}}$ release $(p>0.05$ for DPN and G-1) with correspondingly higher $\mathrm{EC}_{50}$ value of $2.55 \mathrm{nM}$ (95\% CI: 0.45-14.41 nM) for DPN with maximal $\left[\mathrm{Ca}^{2+}\right]_{\mathrm{i}}(588 \pm 16 \mathrm{RFU}, n=33)$ at $10 \mu \mathrm{M}$, and $\mathrm{EC}_{50}$ of $10.0 \mathrm{~nm}(95 \% \mathrm{CI}: 9.8-10.2 \mathrm{~nm})$ for $\mathrm{G}-1$ with maximal $\left[\mathrm{Ca}^{2+}\right]_{\mathrm{i}}(643 \pm 26 \mathrm{RFU}, n=22)$ at $100 \mathrm{nM}$.

\section{$\mathrm{mER} \alpha$ is not involved in STX-and G-1-induced $\left[\mathrm{Ca}^{2+}\right]_{\mathrm{i}}$ signaling}

To determine whether $\mathrm{mER} \alpha$ is important for rapid, intracellular, estradiol signaling, hypothalamic astrocytes from ERKO and wild-type mice were treated with estradiol. The estradiol-induced $\left[\mathrm{Ca}^{2+}\right]_{\mathrm{i}}$ release in wild-type mouse astrocytes (Fig. 3) was similar to that observe in rat astrocytes ( $p>0.05$; Fig. 2) (Kuo et al., $2009 \mathrm{~b})$. The estradiol (1 nM)-induced $\left[\mathrm{Ca}^{2+}\right]_{\mathrm{i}}$ release in wildtype mouse astrocytes was eliminated in the ERKO astrocytes $(p>0.05$ vs control; Fig. 3). Estradiol did not signal through mER $\beta$ since physiological (1 nM) and high dose (100 nM) DPN could not induce a $\left[\mathrm{Ca}^{2+}\right]_{\mathrm{i}}$ response $(p>0.05$ vs control $)$ in ERKO astrocytes. Both STX (1 nM) and G-1 (100 nM) induced significantly elevated $\left[\mathrm{Ca}^{2+}\right]_{\mathrm{i}}$ responses in ERKO astrocytes that were similar to wild-type astrocytes ( $p>0.05$ for STX and G-1; Fig. 3). These results suggest that rapid, estradiol signaling is dependent upon $\operatorname{mER} \alpha$ and astrocytic response to STX and G-1 is independent of $\operatorname{mER} \alpha$.

\section{Role of mGluR1a signaling}

To determine whether the mGluRla is integral to rapid estradiol signaling for $\operatorname{mER} \alpha, \operatorname{mER} \beta$, GPR30, or STX-binding protein, a mGluRla antagonist was used to block and a mGluRla agonist to enhance the rapid $\left[\mathrm{Ca}^{2+}\right]_{\mathrm{i}}$ response. Since PPT (1 nM) and STX (1 $\mathrm{nM})$ generated an estradiol-like $\left[\mathrm{Ca}^{2+}\right]_{\mathrm{i}}$ response, the same doses
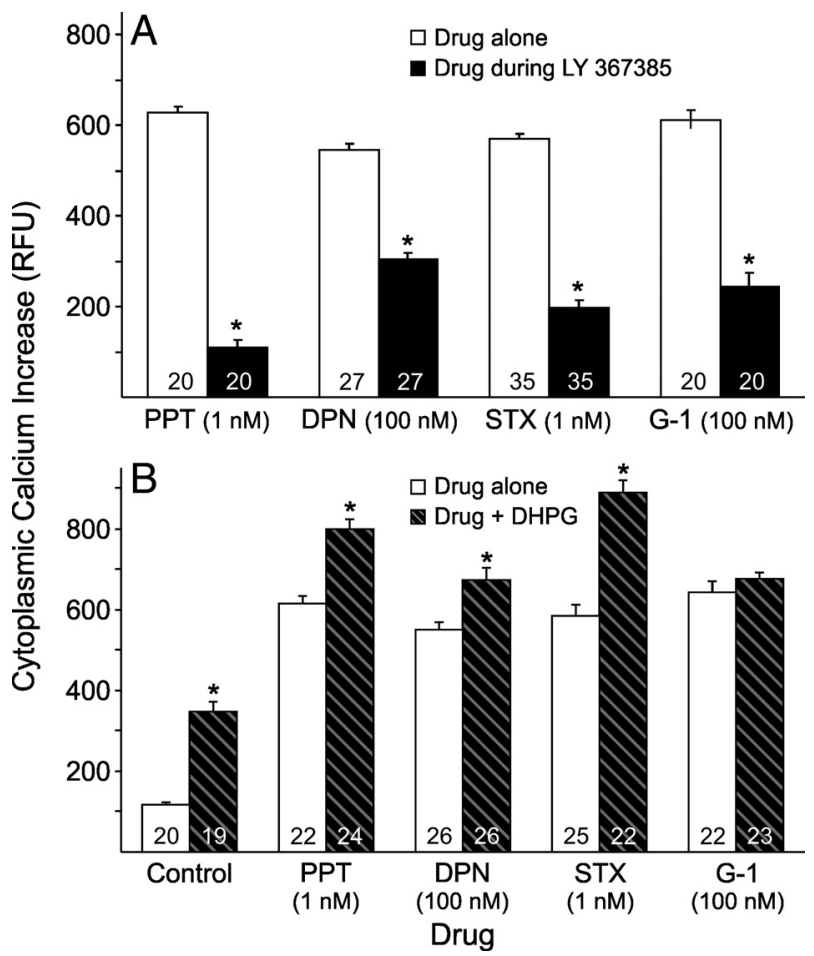

Figure 4. Effect of the mGluR1a on ER agonist-induced $\left[\mathrm{Ca}^{2+}\right]_{\mathrm{i}}$ responses in adult hypothalamic astrocytes. In $\boldsymbol{A}$, the $\left[\mathrm{Ca}^{2+}\right]_{\mathrm{i}}$ levels induced with PPT (1 nM), DPN (100 nM), STX (1 nM), and G-1 (100 nM) were all significantly blocked by LY 367385 (20 nm; $p<0.05)$. In $\boldsymbol{B}$, concurrent DHPG (100 nM) administration significantly enhanced the $\left[\mathrm{Ca}^{2+}\right]_{\mathrm{i}}$ levels induced by PPT (1 nm; $p<0.05)$, DPN (100 nm; $p<0.05)$, and STX (1 nm; $p<0.05)$. However, the $\left[\mathrm{Ca}^{2+}\right]_{\mathrm{i}}$ response induced with G-1 (100 nM) was not enhanced with DHPG (100 nm) exposure $(p>0.05)$. The number of astrocytes for each drug concentration is indicated in the bar graph. Significantly different when comparing drugs (control, PPT, DPN, STX, and/or G-1) in the absence or presence of LY 367385 in $\boldsymbol{A}\left({ }^{*} p<0.05\right.$, paired Student's $t$ test) or in the absence or presence of DHPG in $\boldsymbol{B}\left({ }^{*} p<0.05\right.$, unpaired Student's $t$ test).

were used here. Since DPN and G-1 did not reach an estradiollike $\left[\mathrm{Ca}^{2+}\right]_{\mathrm{i}}$ response until $100 \mathrm{nM}, \mathrm{DPN}$ and $\mathrm{G}-1$ were tested at $100 \mathrm{~nm}$. The mGluRla antagonist, LY 367385 (20 nM), blocked the $\left[\mathrm{Ca}^{2+}\right]_{\mathrm{i}}$ response for all putative mER agonists $(p<0.05$; Fig. $4 A)$. We have previously reported $\left[\mathrm{Ca}^{2+}\right]_{\mathrm{i}}$ responses with the mGluRla agonist DHPG in primary cultures of adult, female hypothalamic astrocytes (Kuo et al., 2009b). DHPG (100 nM) enhanced the $\left[\mathrm{Ca}^{2+}\right]_{\mathrm{i}}$ response for the putative mER agonists $(p<0.05)$, except for G-1 $(p>0.05$; Fig. $4 B)$. These results suggest that rapid intracellular $\left[\mathrm{Ca}^{2+}\right]_{\mathrm{i}}$ signaling by activation of $\operatorname{mER} \alpha, \operatorname{mER} \beta$, and STX-binding protein are all influenced by mGluR1a activity, but GPR30 may signal through another mechanism.

\section{Requirement of mGluR1a for progesterone synthesis}

To determine whether the mGluRla is important for the estradiol-induced progesterone synthesis, astrocytes were pretreated with the mGluRla antagonist, LY 367385. Estradiol (1 $\mathrm{nm})$, PPT (1 nM), STX (1 nM), and G-1 (100 nm) all induced progesterone synthesis in primary, adult, female, hypothalamic astrocyte cultures $(p<0.05)$, but DPN $(100 \mathrm{nM})$ did not $(p>$ 0.05 ; Fig. 5). Therefore, estradiol-stimulated progesterone synthesis does not seem to involve $\operatorname{mER} \beta$ activation. With the exception of G-1, putative mER agonists (estradiol, PPT, and STX) were blocked by pretreatment with LY 367385 (50 nM; $p<0.05$; Fig. 5). These results support a mGluR1a-mER interaction as an essential cell signaling step for the estradiol-induced progester- 


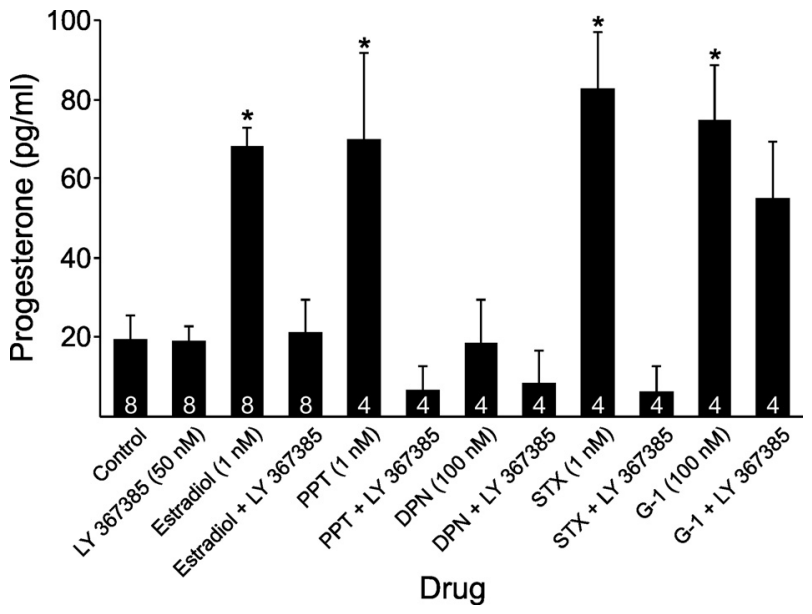

Figure 5. Effect of LY 367385, mGluR1a antagonist, on progesterone synthesis upon exposure to estradiol and several mER agonists in adult hypothalamic astrocytes. LY $367385(50 \mathrm{~nm})$ by itself did not influence progesterone synthesis with levels similar to control $(p>0.05)$. Estradiol (1 nм), PPT (1 nм), STX (1 nм), and G-1 (100 nм) stimulated significantly greater progesterone synthesis than control $(p<0.05)$, but DPN (100 nm) did not ( $p>0.05$ vs control). Progesterone produced by exposure to estradiol (1 nм), PPT (1 nм), and STX (1 nм) was blocked by LY $367385(50 \mathrm{~nm} ; p<0.05)$. However, the G-1 (100 nm)-stimulated progesterone synthesis was not attenuated by LY 367385 (50 nм; $p>0.05$ ). The number of samples for each drug concentration is indicated in the bar graph. Significantly different compared with control $\left({ }^{*} p<\right.$ 0.05 , one-way ANOVA with Student-Newman-Keuls post hoc test).

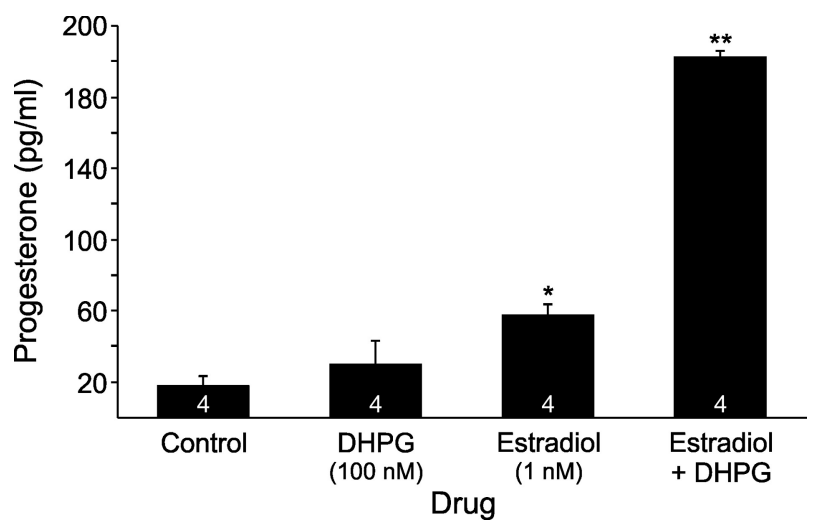

Figure 6. Effect of DHPG, mGluR1a agonist, on estradiol stimulated progesterone synthesis in adult hypothalamic astrocytes. Estradiol at $1 \mathrm{~nm}$ stimulated significant progesterone synthesis $(p<0.05$ vs control or DHPG), but DHPG at $100 \mathrm{~nm}$ did not ( $p>0.05$ vs control). Estradiol ( 1 $\mathrm{nm})$ in combination with DHPG (100 nm) stimulated a much higher progesterone level than estradiol (1 nm) or DHPG (100 nm) alone $(p<0.05)$. The number of samples for each drug concentration is indicated in the bar graph. Significantly different compared with control $\left({ }^{*} p<\right.$ 0.05, one-way ANOVA with Student-Newman-Keuls post hoc test) or compared with all other groups ( ${ }^{* *} p<0.05$, one-way ANOVA with Student-Newman-Keuls post hoc test).

one synthesis, with $\mathrm{mER} \alpha$ and STX-binding protein as the likely mER candidates. LY 367385 did not block the G-1-stimulated progesterone synthesis, suggesting that GPR30 signaling may be independent of the mGluRla.

Simultaneous activation of the mGluRla enhanced the estradiol-stimulated progesterone synthesis. Estradiol at $1 \mathrm{~nm}$ stimulated higher progesterone synthesis compared with DHPG at $100 \mathrm{nM}(p<0.05)$ and control $(p<0.05)$, however, estradiol ( 1 $\mathrm{nM})$ in combination with DHPG (100 nM) induced even greater levels of progesterone ( $p<0.05$ vs estradiol or DHPG; Fig. 6). This result confirms mGluRla transactivation as integral to rapid estradiol signaling and progesterone synthesis in hypothalamic astrocytes.

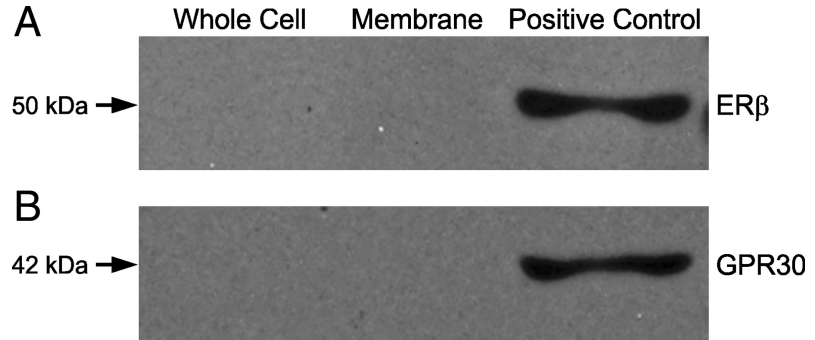

Figure 7. Coimmunoprecipitation of ER $\beta$-mGluR1a and GPR30-mGluR1a from cultured adult hypothalamic astrocytes. The lanes are representative of whole-cell lysate, plasma membrane fraction, and whole-cell lysate without coimmunoprecipitation as a positive control, respectively. In $\boldsymbol{A}$, ER $\beta$-mGluR1a coimmunoprecipitation with mGluR1a antibodies used to pull-down the receptor complex and antibodies against $E R \beta$ used for detection. In $B$, GPR30mGluR1a coimmunoprecipitation with mGluR1a antibodies used in the pull-down phase and the complex detected with GPR30 antibodies. The mGluR1a did not coimmunoprecipitate with ER $\beta$ or GPR30 within the plasma membrane fraction or whole-cell lysate.

\section{mGluR1a does not coimmunoprecipitate with mER $\beta$ or GPR30}

We have previously shown through coimmunoprecipitation experiments that $\mathrm{ER} \alpha$ can directly interact with mGluRla in astrocyte membranes (Kuo et al., 2009b). A similar coimmunoprecipitation experiment determined whether ER $\beta$ or GPR30 can directly interact with mGluRla. Metabotropic GluR1a was immunoprecipitated from whole-cell lysates and membrane fractions, then rabbit polyclonal antibodies against $\operatorname{ER} \beta$ (Fig. $7 A$ ) or rabbit polyclonal antibodies against GPR30 (Fig. 7B) were used to detect protein coprecipitation with Western blots. Although ER $\beta$ has been detected in astrocyte plasma membranes (Chaban et al., 2004), we could not demonstrate a potential interaction between $\mathrm{ER} \beta$ and mGluRla in the whole-cell lysates or the plasma membrane fraction (Fig. 7A). The order of the experiment was repeated in the reverse direction for $\mathrm{ER} \beta$. ER $\beta$ was immunoprecipitated and rabbit polyclonal antibodies against mGluRla were used for protein coprecipitation with Western blotting that confirmed the lack of direct interaction between ER $\beta$ and mGluR1a in whole-cell lysates or the membrane fraction (data not shown). Although GPR30 could be detected in hypothalamic astrocytes by Western blotting (supplemental Fig. 1, available at www.jneurosci.org as supplemental material), GPR30 did not coimmunoprecipite with mGluRla in whole-cell lysates or the plasma membrane fraction (Fig. 7B), consistent with other studies that could not demonstrate GPR30 in the plasma membrane (Revankar et al., 2005; Gorosito et al., 2008; Bondar et al., 2009). This suggests that G-1 may act directly on the mGluRla.

\section{Discussion}

These experiments demonstrate astrocytic response to activation of several putative mERs, including $\mathrm{ER} \alpha$, STX-activated protein, and GPR30. Two related physiological endpoints were used: stimulation of $\left[\mathrm{Ca}^{2+}\right]_{i}$ release and facilitation of progesterone synthesis. These responses of hypothalamic astrocytes are critical components of the CNS-mediated estrogen-positive feedback mechanism (Micevych and Sinchak, 2008a). When estradiol levels peak on proestrus, locally synthesized hypothalamic neuroprogesterone is stimulated, mainly in astrocytes (Zwain and Yen, 1999; Micevych et al., 2003, 2007, 2008). This increase in hypothalamic neuroprogesterone activates progesterone receptors obligatory for initiation of the preovulatory LH surge (Rao and Mahesh, 1986; Chappell and Levine, 2000; Micevych et al., 2003).

While $100 \mathrm{pm}$ estradiol stimulated $\left[\mathrm{Ca}^{2+}\right]_{\mathrm{i}}$ release, progesterone synthesis required $1 \mathrm{~nm}$ estradiol indicating that a threshold 
level of $\left[\mathrm{Ca}^{2+}\right]_{i}$ was required. This "step function" fits well with physiological levels of estradiol reached during proestrus (Butcher et al., 1974; Hawkins et al., 1975; Shaikh and Shaikh, 1975) and supports neuroprogesterone as a mechanism for regulating the transition from estrogen-negative to estrogenpositive feedback. Another important finding was the rapidity of this progesterone synthesis, such that 5 min of estradiol treatment stimulated significant progesterone levels. Membranemediated estradiol signaling in neurons and astrocytes is dependent upon $\mathrm{ER} \alpha$ transactivation of mGluR1a, which activates the PLC pathway releasing $\mathrm{IP}_{3}$ receptor-sensitive stores of intracellular $\mathrm{Ca}^{2+}$ from the smooth endoplasmic reticulum (Beyer and Raab, 1998; Chaban et al., 2004; Boulware et al., 2005; Dewing et al., 2007; Micevych and Mermelstein, 2008; Kuo et al., 2009b). Estradiol-stimulated progesterone synthesis in hypothalamic astrocytes was also dependent on the mGluR1a. Moreover, estradiol-stimulated progesterone synthesis was enhanced by DHPG, suggesting that, in addition to the mGluRla coupled with $\operatorname{ER} \alpha$, an additional population of mGluRla can potentially be stimulated by local neuronal activity through glutamate release.

A preponderance of evidence suggests that membraneinitiated estradiol action is mediated through $\operatorname{mER} \alpha$ or $\operatorname{mER} \beta$ (Razandi et al., 1999; Wade et al., 2001; Chaban et al., 2004; Pawlak et al., 2005; Mhyre and Dorsa, 2006; Pedram et al., 2006; Bondar et al., 2009; Hirahara et al., 2009; Kuo et al., 2009b). Preliminary data with ovariectomized ERKO mice in vivo treated with $17 \beta$-estradiol benzoate $(10 \mu \mathrm{g})$ failed to significantly increase hypothalamic progesterone levels $(2.14 \pm 0.66$ vs $1.83 \pm$ $0.35 \mathrm{pg} / \mathrm{mg}$ tissue in controls, $n=6, p>0.05)$ that was seen in ovariectomized wild-type mice $(10.27 \pm 3.67$ vs $1.07 \pm 0.51$ $\mathrm{pg} / \mathrm{mg}$ tissue in controls, $n=6, p<0.05$ ) (J. Kuo, N. Hamid, and P. Micevych, unpublished observation). Consistent with these data, ER $\alpha$ appears to be primarily responsible for the rapid signaling in astrocytes (Pawlak et al., 2005; Bondar et al., 2009; Kuo et al., 2009b). Surface biotinylation demonstrated estradioldependent $\mathrm{ER} \alpha$ trafficking to the plasma membrane in hypothalamic astrocytes (Bondar et al., 2009). Furthermore, PPT, a potent, selective ER $\alpha$ agonist with 410 -fold higher binding affinity for $\operatorname{ER} \alpha$ vs ER $\beta$ (Stauffer et al., 2000), induced similar $\left[\mathrm{Ca}^{2+}\right]_{\text {i }}$ responses to estradiol in astrocytes at $1 \mathrm{nM}, 10 \mathrm{nM}$, and $100 \mathrm{~nm}$. Interestingly, $100 \mathrm{pM}$ PPT produced greater $\left[\mathrm{Ca}^{2+}\right]_{\mathrm{i}}$ release than equimolar estradiol. This result was unexpected since the relative binding affinity of PPT to ER $\alpha$ is $49 \%$ less than estradiol's binding to $\mathrm{ER} \alpha$ and transcriptional activation by $\mathrm{ER} \alpha$ is approximately tenfold higher for estradiol than PPT (Stauffer et al., 2000). However, binding assays using purified ERs investigate isolated ligand-receptor interactions and gene transcription assays involve nuclear, genomic responses, whereas physiological tests of membrane initiated signaling require additional interaction of the ligand-receptor complex with mGluRla and other cellular components in which PPT may be more efficacious. It is possible that PPT may preferentially activate $\operatorname{mER} \alpha$ compared with nuclear ER $\alpha$, or PPT may activate other mERs in addition to $\operatorname{mER} \alpha$ (Thammacharoen et al., 2009). Progesterone synthesis was equally facilitated by $1 \mathrm{~nm}$ PPT and $1 \mathrm{~nm}$ estradiol. LY 367385 inhibited both the PPT-induced $\left[\mathrm{Ca}^{2+}\right]_{\mathrm{i}}$ release and progesterone synthesis, supporting an intracellular signaling mechanism involving $\operatorname{mER} \alpha$ transactivation of mGluRla. As with estradiol, DHPG significantly enhanced the PPT-induced $\left[\mathrm{Ca}^{2+}\right]_{\mathrm{i}}$ response (Kuo et al., 2009b). Overall, our results with PPT are consistent with the hypothesis that $\mathrm{ER} \alpha$ is the $\mathrm{mER}$ responsible for rapid, nongenomic estradiol signaling in hypothalamic astrocytes.
Converging evidence indicates that estradiol does not act through $\operatorname{mER} \beta$ to induce $\left[\mathrm{Ca}^{2+}\right]_{\mathrm{i}}$ release and progesterone synthesis. First, the selective ER $\beta$ agonist, DPN, did not induce a rapid $\left[\mathrm{Ca}^{2+}\right]_{\mathrm{i}}$ release in ERKO astrocytes. Second, DPN induced lower levels of $\left[\mathrm{Ca}^{2+}\right]_{i}$ compared with equimolar estradiol. The DPN-induced $\left[\mathrm{Ca}^{2+}\right]_{\mathrm{i}}$ response was blocked by LY 367385, but ER $\beta$ did not coimmunoprecipitate with mGluR1a. These results suggest that the DPN responses were due to activation of ER $\alpha$ since DPN is a selective agonist with a 70 -fold higher relative binding affinity and 30- to 170 -fold higher relative potency for $\mathrm{ER} \beta$ vs ER $\alpha$ (Meyers et al., 2001; Harrington et al., 2003). Physiologically, $100 \mathrm{nM}$ DPN stimulated $\left[\mathrm{Ca}^{2+}\right]_{\mathrm{i}}$ levels equivalent to 1 nM PPT. Interestingly, the $\mathrm{EC}_{50}$ for DPN was 90 -fold higher relative to PPT. Despite this, $100 \mathrm{~nm} \mathrm{DPN}$ failed to stimulate progesterone synthesis. This result may be partially explained by predominant ER $\beta$ activation, which opposes the actions of ER $\alpha$ in reproductive tissues (Matthews and Gustafsson, 2003). Therefore, our results support a role for $\operatorname{ER} \alpha$, but not $\operatorname{ER} \beta$, in rapid, membrane-initiated estradiol signaling (Wintermantel et al., 2006; Dewing et al., 2007).

The present results suggest that other putative mERs can also mediate estradiol stimulation of astrocytes. STX is a diphenylacrylamide SERM related to tamoxifen that activates G $\alpha$ q (Qiu et al., 2003). STX is efficacious in double $\mathrm{ER} \alpha / \mathrm{ER} \beta$ knock-out mice, but blocked with the ER antagonist ICI 182,780 (Qiu et al., 2006). STX does not activate $\mathrm{ER} \alpha$ or $\mathrm{ER} \beta$ having a millionfold lower binding affinity compared with estradiol (Qiu et al., 2003). In astrocytes, STX increased $\left[\mathrm{Ca}^{2+}\right]_{\mathrm{i}}$ release and progesterone synthesis. Downstream, estradiol and STX appear to activate the same PLC pathway, but through a different receptor since STX stimulated $\left[\mathrm{Ca}^{2+}\right]_{\mathrm{i}}$ release in ERKO astrocytes, where estradiol was ineffective. The STX-binding protein appears to transactivate the mGluRla since the STX effect was abrogated with LY 367385. As with estradiol and PPT, DHPG augmented the STX-induced $\left[\mathrm{Ca}^{2+}\right]_{\mathrm{i}}$ response (Kuo et al., 2009b). As soon as this receptor is characterized, we will test whether mGluR1a and STX-activated protein interact, as suggested by the present results. Although not supported by our results, in another model, STX has been reported to signal through GPR30 (Lin et al., 2009). In that experiment, small interfering RNA directed against GPR30 abolished the STX-induced transcription.

Another putative mER is GPR30, a GPCR that activates adenylyl cyclase in breast cancer cells lacking both $\operatorname{ER} \alpha$ and ER $\beta$ (Filardo et al., 2000, 2002; Revankar et al., 2005; Thomas et al., 2005). Although FLAG- and hemagglutinin-tagged GPR30 have been reported at the cell membrane (Funakoshi et al., 2006; Filardo et al., 2007), GPR30 could not be identified at the plasma membrane in native cells (Gorosito et al., 2008; Bondar et al., 2009). Intracellular GPR30 has been localized in the endoplasmic reticulum and Golgi apparatus (Revankar et al., 2005). The reasons for this discrepancy are not clear and may be related to differences in the antibodies or cells used. Moreover, it is unclear whether tagging GPR30 may affect its processing and cellular localization. The GPR30 agonist G-1 was less potent than estradiol at inducing $\left[\mathrm{Ca}^{2+}\right]_{\mathrm{i}}$ release, requiring $100 \mathrm{nM}$ for a maximal response. Our $\mathrm{EC}_{50}$ for $\mathrm{G}-1$ was similar to that previously reported ( $\sim 2 \mathrm{~nm}$ ) (Bologa et al., 2006). Similar to the $\mathrm{mER} \alpha$ and oxytocin receptor signaling pathways, the G-1-induced $\left[\mathrm{Ca}^{2+}\right]_{\mathrm{i}}$ release was blocked by LY 367385 suggesting an interaction with mGluRla (Kuo et al., 2009a,b). However, GPR30 was not detected in the plasma membrane fraction, could not be labeled with surface biotinylation, and did not coimmunoprecipitate with mGluR1a (Bondar et al., 2009). We speculate that G-1 stim- 
ulates mGluR1a directly on the plasma membrane, which is sensitive to LY 367385. G-1 can also activate intracellular receptors resulting in a GPR30-mediated release of intracellular calcium that stimulates progesterone synthesis not antagonized by LY 367385. This idea is supported by the lack of DHPG augmentation of the G-1-stimulated $\left[\mathrm{Ca}^{2+}\right]_{\mathrm{i}}$ release. Overall, our results suggest that G-1 signals through a different mechanism than estradiol.

In summary, our results suggest that several putative mERs are involved in regulation of $\left[\mathrm{Ca}^{2+}\right]_{i}$ release and progesterone synthesis in astrocytes. The evidence is strongest for $\operatorname{ER} \alpha$ and STX activated G $\alpha \mathrm{q}-\mathrm{mER}$. These proteins act as membrane receptors that interact with mGluRla to initiate cell signaling. From a reproductive perspective and experiments with ERKO mice and astrocytes, $\operatorname{mER} \alpha$ is the primary ER responsible for the rapid increase in hypothalamic neuroprogesterone. The STX-binding protein signaling pathway is independent from $\operatorname{mER} \alpha$. GPR30 is an intriguing receptor and appears to have a role as an intracellular mediator of $\left[\mathrm{Ca}^{2+}\right]_{i}$ release. Our data does not support rapid, membrane-initiated estradiol signaling through $\operatorname{mER} \beta$ in hypothalamic astrocytes that synthesize progesterone. In conclusion, these results demonstrate that estradiol activates $\operatorname{mER} \alpha$ on hypothalamic astrocytes and estradiol signaling is most effective on astrocytes near active glutamatergic nerve terminals.

\section{References}

Acconcia F, Ascenzi P, Bocedi A, Spisni E, Tomasi V, Trentalance A, Visca P, Marino M (2005) Palmitoylation-dependent estrogen receptor alpha membrane localization: regulation by 17beta-estradiol. Mol Biol Cell $16: 231-237$.

Beyer C, Raab H (1998) Nongenomic effects of oestrogen: embryonic mouse midbrain neurones respond with a rapid release of calcium from intracellular stores. Eur J Neurosci 10:255-262.

Bologa CG, Revankar CM, Young SM, Edwards BS, Arterburn JB, Kiselyov AS, Parker MA, Tkachenko SE, Savchuck NP, Sklar LA, Oprea TI, Prossnitz ER (2006) Virtual and biomolecular screening converge on a selective agonist for GPR30. Nat Chem Biol 2:207-212.

Bondar G, Kuo J, Hamid N, Micevych P (2009) Estradiol-induced estrogen receptor-alpha trafficking. J Neurosci 29:15323-15330.

Boulware MI, Weick JP, Becklund BR, Kuo SP, Groth RD, Mermelstein PG (2005) Estradiol activates group I and II metabotropic glutamate receptor signaling, leading to opposing influences on cAMP response elementbinding protein. J Neurosci 25:5066-5078.

Bradford MM (1976) A rapid and sensitive method for the quantitation of microgram quantities of protein utilizing the principle of protein-dye binding. Anal Biochem 72:248-254.

Brailoiu E, Dun SL, Brailoiu GC, Mizuo K, Sklar LA, Oprea TI, Prossnitz ER, Dun NJ (2007) Distribution and characterization of estrogen receptor G protein-coupled receptor 30 in the rat central nervous system. J Endocrinol 193:311-321.

Butcher RL, Collins WE, Fugo NW (1974) Plasma concentration of LH, FSH, prolactin, progesterone and estradiol-17beta throughout the 4-day estrous cycle of the rat. Endocrinology 94:1704-1708.

Chaban VV, Lakhter AJ, Micevych P (2004) A membrane estrogen receptor mediates intracellular calcium release in astrocytes. Endocrinology 145:3788-3795.

Chappell PE, Levine JE (2000) Stimulation of gonadotropin-releasing hormone surges by estrogen. I. Role of hypothalamic progesterone receptors. Endocrinology 141:1477-1485.

Dewing P, Boulware MI, Sinchak K, Christensen A, Mermelstein PG, Micevych P (2007) Membrane estrogen receptor-alpha interactions with metabotropic glutamate receptor 1a modulate female sexual receptivity in rats. J Neurosci 27:9294-9300.

Filardo EJ, Quinn JA, Bland KI, Frackelton AR Jr (2000) Estrogen-induced activation of Erk-1 and Erk-2 requires the G protein-coupled receptor homolog, GPR30, and occurs via trans-activation of the epidermal growth factor receptor through release of HB-EGF. Mol Endocrinol 14:1649-1660.

Filardo EJ, Quinn JA, Frackelton AR Jr, Bland KI (2002) Estrogen action via the G protein-coupled receptor, GPR30: stimulation of adenylyl cyclase and cAMP-mediated attenuation of the epidermal growth factor receptor-to-MAPK signaling axis. Mol Endocrinol 16:70-84.

Filardo E, Quinn J, Pang Y, Graeber C, Shaw S, Dong J, Thomas P (2007) Activation of the novel estrogen receptor $G$ protein-coupled receptor 30 (GPR30) at the plasma membrane. Endocrinology 148:3236-3245.

Funakoshi T, Yanai A, Shinoda K, Kawano MM, Mizukami Y (2006) G protein-coupled receptor 30 is an estrogen receptor in the plasma membrane. Biochem Biophys Res Commun 346:904-910.

Garcia-Segura LM, Naftolin F, Hutchison JB, Azcoitia I, Chowen JA (1999) Role of astroglia in estrogen regulation of synaptic plasticity and brain repair. J Neurobiol 40:574-584.

Gorosito SV, Lorenzo AG, Cambiasso MJ (2008) Estrogen receptor alpha is expressed on the cell-surface of embryonic hypothalamic neurons. Neuroscience 154:1173-1177.

Harrington WR, Sheng S, Barnett DH, Petz LN, Katzenellenbogen JA, Katzenellenbogen BS (2003) Activities of estrogen receptor alpha- and beta-selective ligands at diverse estrogen responsive gene sites mediating transactivation or transrepression. Mol Cell Endocrinol 206:13-22.

Hawkins RA, Freedman B, Marshall A, Killen E (1975) Oestradiol-17 beta and prolactin levels in rat peripheral plasma. Br J Cancer 32:179-185.

Hirahara Y, Matsuda K, Gao W, Arvanitis DN, Kawata M, Boggs JM (2009) The localization and non-genomic function of the membrane-associated estrogen receptor in oligodendrocytes. Glia 57:153-165.

Ivanova T, Karolczak M, Beyer C (2001) Estrogen stimulates the mitogenactivated protein kinase pathway in midbrain astroglia. Brain Res 889:264-269.

Kelly MJ, Moss RL, Dudley CA (1976) Differential sensitivity of preopticseptal neurons to microelectrophoresed estrogen during the estrous cycle. Brain Res 114:152-157.

Kuo J, Hariri OR, Micevych P (2009a) An interaction of oxytocin receptors with metabotropic glutamate receptors in hypothalamic astrocytes. J Neuroendocrinol 21:1001-1006.

Kuo J, Hariri OR, Bondar G, Ogi J, Micevych P (2009b) Membrane estrogen receptor-alpha interacts with metabotropic glutamate receptor type la to mobilize intracellular calcium in hypothalamic astrocytes. Endocrinology 150:1369-1376.

Lagrange AH, Rønnekleiv OK, Kelly MJ (1995) Estradiol-17 beta and muopioid peptides rapidly hyperpolarize GnRH neurons: a cellular mechanism of negative feedback? Endocrinology 136:2341-2344.

Lin BC, Suzawa M, Blind RD, Tobias SC, Bulun SE, Scanlan TS, Ingraham HA (2009) Stimulating the GPR30 estrogen receptor with a novel tamoxifen analogue activates SF-1 and promotes endometrial cell proliferation. Cancer Res 69:5415-5423.

Matthews J, Gustafsson JA (2003) Estrogen signaling: a subtle balance between ER alpha and ER beta. Mol Interv 3:281-292.

McCarthy KD, de Vellis J (1980) Preparation of separate astroglial and oligodendroglial cell cultures from rat cerebral tissue. J Cell Biol 85:890-902.

Meyers MJ, Sun J, Carlson KE, Marriner GA, Katzenellenbogen BS, Katzenellenbogen JA (2001) Estrogen receptor-beta potency-selective ligands: structure-activity relationship studies of diarylpropionitriles and their acetylene and polar analogues. J Med Chem 44:4230-4251.

Mhyre AJ, Dorsa DM (2006) Estrogen activates rapid signaling in the brain: role of estrogen receptor alpha and estrogen receptor beta in neurons and glia. Neuroscience 138:851-858.

Micevych P, Sinchak K (2008a) Estradiol regulation of progesterone synthesis in the brain. Mol Cell Endocrinol 290:44-50.

Micevych P, Sinchak K (2008b) Synthesis and function of hypothalamic neuroprogesterone in reproduction. Endocrinology 149:2739-2742.

Micevych PE, Mermelstein PG (2008) Membrane estrogen receptors acting through metabotropic glutamate receptors: an emerging mechanism of estrogen action in brain. Mol Neurobiol 38:66-77.

Micevych P, Sinchak K, Mills RH, Tao L, LaPolt P, Lu JK (2003) The luteinizing hormone surge is preceded by an estrogen-induced increase of hypothalamic progesterone in ovariectomized and adrenalectomized rats. Neuroendocrinology 78:29-35.

Micevych PE, Chaban V, Ogi J, Dewing P, Lu JK, Sinchak K (2007) Estradiol stimulates progesterone synthesis in hypothalamic astrocyte cultures. Endocrinology 148:782-789.

Micevych P, Soma KK, Sinchak K (2008) Neuroprogesterone: key to estrogen positive feedback? Brain Res Rev 57:470-480.

Pawlak J, Karolczak M, Krust A, Chambon P, Beyer C (2005) Estrogen 
receptor-alpha is associated with the plasma membrane of astrocytes and coupled to the MAP/Src-kinase pathway. Glia 50:270-275.

Pedram A, Razandi M, Levin ER (2006) Nature of functional estrogen receptors at the plasma membrane. Mol Endocrinol 20:1996-2009.

Pedram A, Razandi M, Sainson RC, Kim JK, Hughes CC, Levin ER (2007) A conserved mechanism for steroid receptor translocation to the plasma membrane. J Biol Chem 282:22278-22288.

Qiu J, Bosch MA, Tobias SC, Grandy DK, Scanlan TS, Ronnekleiv OK, Kelly MJ (2003) Rapid signaling of estrogen in hypothalamic neurons involves a novel G-protein-coupled estrogen receptor that activates protein kinase C. J Neurosci 23:9529-9540.

Qiu J, Bosch MA, Tobias SC, Krust A, Graham SM, Murphy SJ, Korach KS, Chambon P, Scanlan TS, Rønnekleiv OK, Kelly MJ (2006) A G-proteincoupled estrogen receptor is involved in hypothalamic control of energy homeostasis. J Neurosci 26:5649-5655.

Quesada A, Romeo HE, Micevych P (2007) Distribution and localization patterns of estrogen receptor-beta and insulin-like growth factor-1 receptors in neurons and glial cells of the female rat substantia nigra: localization of ERbeta and IGF-1R in substantia nigra. J Comp Neurol 503:198-208.

Rao IM, Mahesh VB (1986) Role of progesterone in the modulation of the preovulatory surge of gonadotropins and ovulation in the pregnant mare's serum gonadotropin-primed immature rat and the adult rat. Biol Reprod 35:1154-1161.

Razandi M, Pedram A, Greene GL, Levin ER (1999) Cell membrane and nuclear estrogen receptors (ERs) originate from a single transcript: studies of ERalpha and ERbeta expressed in Chinese hamster ovary cells. Mol Endocrinol 13:307-319.

Revankar CM, Cimino DF, Sklar LA, Arterburn JB, Prossnitz ER (2005) A transmembrane intracellular estrogen receptor mediates rapid cell signaling. Science 307:1625-1630.

Sakamoto H, Matsuda K, Hosokawa K, Nishi M, Morris JF, Prossnitz ER, Kawata M (2007) Expression of G protein-coupled receptor-30, a G protein-coupled membrane estrogen receptor, in oxytocin neurons of the rat paraventricular and supraoptic nuclei. Endocrinology 148:5842-5850.

Shaikh AA, Shaikh SA (1975) Adrenal and ovarian steroid secretion in the rat estrous cycle temporally related to gonadotropins and steroid levels found in peripheral plasma. Endocrinology 96:37-44.

Sinchak K, Mills RH, Tao L, LaPolt P, Lu JK, Micevych P (2003) Estrogen induces de novo progesterone synthesis in astrocytes. Dev Neurosci 25:343-348.

Stauffer SR, Coletta CJ, Tedesco R, Nishiguchi G, Carlson K, Sun J, Katzenellenbogen BS, Katzenellenbogen JA (2000) Pyrazole ligands: structure-affinity/ activity relationships and estrogen receptor-alpha-selective agonists. J Med Chem 43:4934-4947.

Szego CM, Davis JS (1967) Adenosine 3', $5^{\prime}$-monophosphate in rat uterus: acute elevation by estrogen. Proc Natl Acad Sci U S A 58:1711-1718.

Thammacharoen S, Geary N, Lutz TA, Ogawa S, Asarian L (2009) Divergent effects of estradiol and the estrogen receptor-alpha agonist PPT on eating and activation of PVN CRH neurons in ovariectomized rats and mice. Brain Res 1268:88-96.

Thomas P, Pang Y, Filardo EJ, Dong J (2005) Identity of an estrogen membrane receptor coupled to a $\mathrm{G}$ protein in human breast cancer cells. Endocrinology 146:624-632.

Wade CB, Robinson S, Shapiro RA, Dorsa DM (2001) Estrogen receptor (ER)alpha and ERbeta exhibit unique pharmacologic properties when coupled to activation of the mitogen-activated protein kinase pathway. Endocrinology 142:2336-2342.

Wintermantel TM, Campbell RE, Porteous R, Bock D, Gröne HJ, Todman MG, Korach KS, Greiner E, Pérez CA, Schütz G, Herbison AE (2006) Definition of estrogen receptor pathway critical for estrogen positive feedback to gonadotropin-releasing hormone neurons and fertility. Neuron 52:271-280.

Zwain IH, Yen SS (1999) Neurosteroidogenesis in astrocytes, oligodendrocytes, and neurons of cerebral cortex of rat brain. Endocrinology 140: 3843-3852. 